\title{
Low-temperature constraints on the Cenozoic thermal evolution of the Southern Rhodope Core Complex (Northern Greece)
}

\author{
Alexandre Kounov $\cdot$ Eliane Wüthrich · Diane Seward • \\ Jean-Pierre Burg • Daniel Stockli
}

Received: 20 September 2014 / Accepted: 5 February 2015 / Published online: 17 February 2015

(C) Springer-Verlag Berlin Heidelberg 2015

\begin{abstract}
The South Rhodope Core Complex (SRCC) of Northern Greece is probably the most studied metamorphic core complex of the Rhodope Massif, and yet its geological evolution has not yet been fully unravelled, especially the later stages of its thermotectonic evolution. We applied the fission-track method on apatite and zircon and the [U-Th-(Sm)]/He method on apatite in order to reconstruct the low-temperature thermal history. The main detachments responsible for the unroofing of the core complex are the Kerdilion and the Strymon Valley detachments. The Kerdilion detachment initiated the exhumation of the SRCC at the latest at $42 \mathrm{Ma}$ and controlled it until about 24 Ma. Between 24 and 12 Ma, the Strymon Valley detachment accommodated the exhumation. Since $12 \mathrm{Ma}$ brittle normal faults, some of them cutting the Strymon Valley detachment were responsible for the final cooling of the basement rocks in the studied area and the formation of syn-tectonic sedimentary basins. Activity along these brittle normal faults lasted until $6 \mathrm{Ma}$ or probably
\end{abstract}

\footnotetext{
A. Kounov $(\bowtie)$

Institute of Geology and Paleontology, Basel University, 4056 Basel, Switzerland

e-mail: a.kounov@unibas.ch

E. Wüthrich · J.-P. Burg

Geological Institute, ETH-Zentrum, 8092 Zurich, Switzerland

D. Seward

School of Geography, Environment and Earth Sciences, Victoria

University, Wellington, New Zealand

D. Stockli

Department of Geological Sciences, University of Texas

at Austin, Austin, TX 78712, USA
}

even until today, as indicated by recent seismic activity in the area.

Keywords Thermochronology $\cdot$ Rhodope $\cdot$ Core complex $\cdot$ Exhumation $\cdot$ Fission-track analysis $\cdot$ Greece

\section{Introduction}

Cenozoic extension, in the southern region of the Balkan Peninsula, particularly in the Rhodope Massif (Fig. 1) has been the focus of attention during the last two decades (e.g. Dinter and Royden 1993; Sokoutis et al. 1993; Burg et al. 1995, 1996; Dinter 1998; Ricou et al. 1998; Krohe and Mposkos 2002; Bonev et al. 2006; Brun and Sokoutis 2007; Jahn-Awe et al. 2012). Both structural and geochronological studies have confirmed that this crystalline terrane represents deeply denuded Cenozoic metamorphic core complexes (e.g. Krohe and Mposkos 2002; Bonev et al. 2006; Brun and Sokoutis 2007). Following Cretaceous subduction/collision associated with thickening of the crust, these complexes represent and reveal a period of extension driven by the retreat of the subducting slab and/or postcollisional collapse (e.g. Krohe and Mposkos 2002; Bonev et al. 2006; Brun and Sokoutis 2007; Nagel et al. 2011). Until recently, extension in the Rhodope was considered to have initiated simultaneously with extension in the Cyclades during the late Oligocene to early Miocene (synthesis in Gautier et al. 1999). However, there is growing evidence that the extension in the Rhodope had already been initiated during middle Eocene times (Burchfiel et al. 2000; Kounov et al. 2004; Brun and Sokoutis 2007), some 5-10 Ma earlier than in the Cyclades (Forster and Lister 2009).

The Southern Rhodope Core Complex (SRCC, Brun and Sokoutis 2007) is one of the most extensively studied 


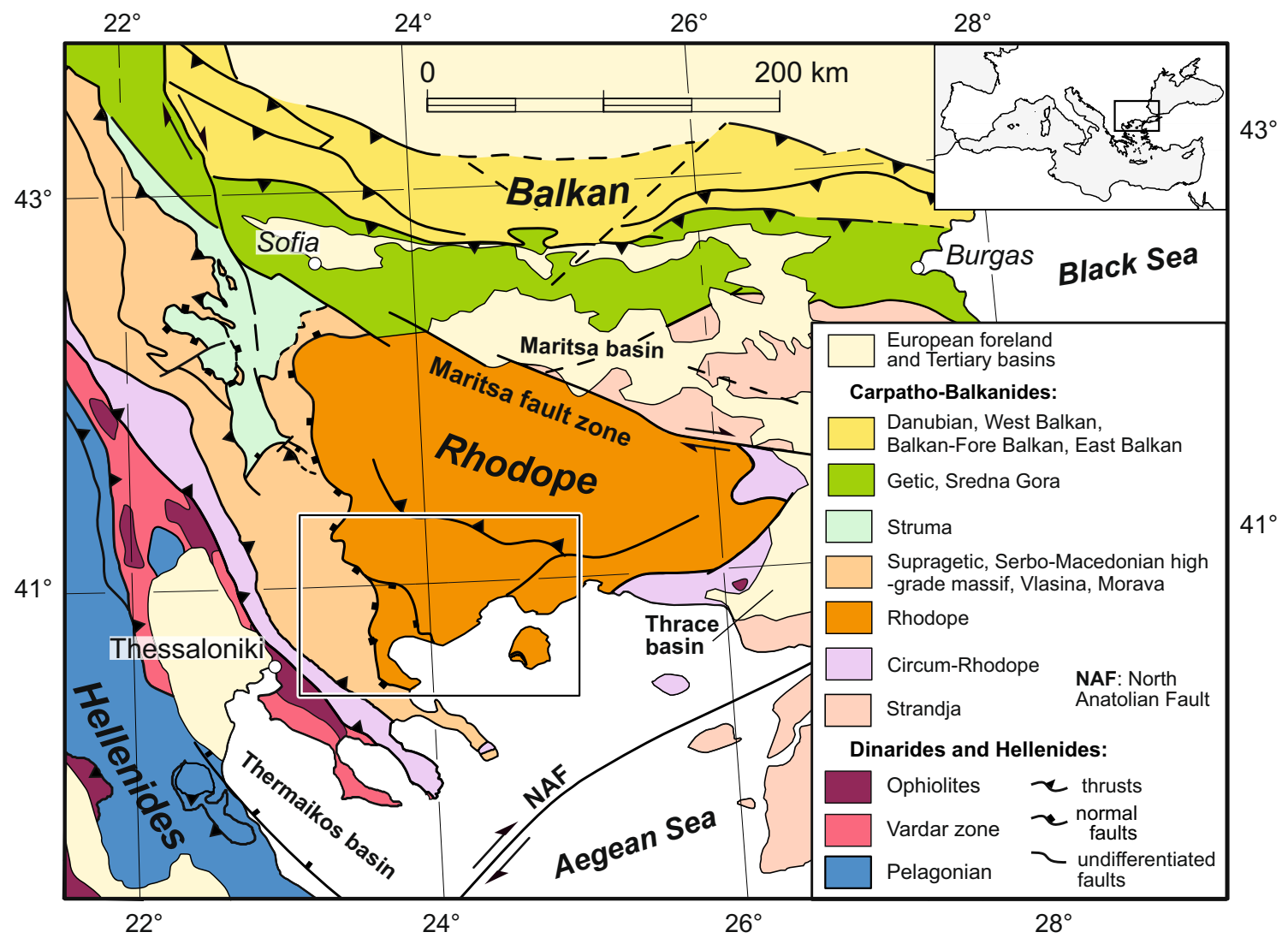

Fig. 1 Tectonic map of the south-western Balkan Peninsula [modified from Schmid et al. (2008)]. Box outlines Fig. 2

core complexes within the Rhodope (Fig. 2). Structural and geochronological data point to large-scale syn-metamorphic extension since the middle Eocene (Brun and Sokoutis 2007). The relative age and significance of the different major low-angle normal faults along which the extension was accommodated are, however, still controversial. The northern limit of the SRCC is the NW-SEtrending Nestos thrust. The south-western boundary of the SRCC has been variously located either along the Strymon Valley detachment (Dinter and Royden 1993) or the Kerdilion detachment (Brun and Sokoutis 2007; Fig. 2).

In order to understand the role of each of these faults over time and the associated unroofing of the core, we have employed fission-track (FT) analyses on zircon and apatite as well as $[\mathrm{U}-\mathrm{Th}-(\mathrm{Sm})] / \mathrm{He}$ analyses on apatite. These methods are suitable for revealing the timing of the thermotectonic events that have shaped the SRCC between temperatures of $\sim 300$ and $\sim 40{ }^{\circ} \mathrm{C}$, which correspond approximately to the field of brittle deformation processes. The results have allowed us to reconstruct differential movements of individual blocks bounded by normal faults and have led us to propose a new model for the later stages in the evolution of the SRCC.

\section{Geological setting}

\section{The Rhodope Massif}

The Rhodope Massif is located in Southern Bulgaria and Northern Greece (Fig. 1). It is separated towards the north from the Sredna Gora and Strandja tectonic units by the Maritsa fault zone and the Neogene-Quaternary deposits of the Maritsa basin (Fig. 1). The Serbo-Macedonian Massif (SMM) is bordering the Rhodope Massif to the south-west. Based on similarities in metamorphic grade and structural style, the Rhodope and the SMM are often viewed as a single tectonic element (e.g. Burg et al. 1995; Ricou et al. 1998). Nevertheless, recent studies showed that these two units have very different Cenozoic evolution, whereby the SMM escaped the high-grade overprint (Georgiev et al. 2010; Kounov et al. 2010, 2012). To the east, the Rhodope Massif disappears below the Neogene sedimentary cover of the Thrace basin (Fig. 1; Görur and Okay 1996). The Aegean Sea, a Miocene to recent back-arc basin, forms the southern limit of the exposed part of the Rhodope.

The Rhodope Massif is composed of a stack of largescale, south-vergent nappes (e.g. Burg et al. 1990, 1996; Burg 2012) of high-grade metamorphic and igneous rocks 


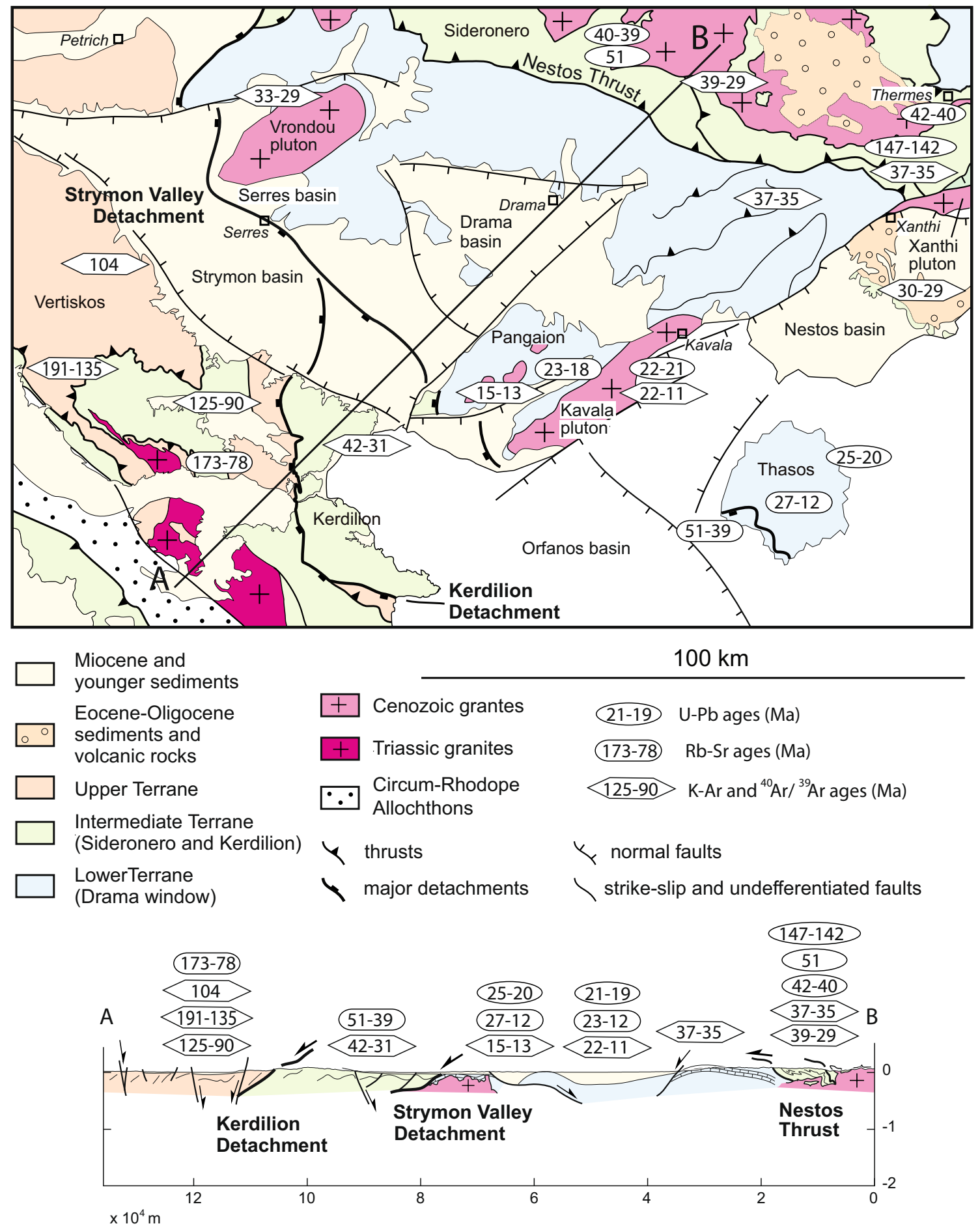

Fig. 2 Geological map of the South Rhodope Core Complex (SRCC) after Burg et al. (1996), Dinter and Royden (1993), Wawrzenitz and Krohe (1998) and Sokoutis et al. (1993) with published geochronological data. $\mathrm{K}-\mathrm{Ar}$ ages on hornblende, muscovite and biotite are from Papadopoulos and Kilias (1985), Harre et al. (1968) and Liati (1986). ${ }^{40} \mathrm{Ar} /{ }^{39} \mathrm{Ar}$ ages on hornblende, biotite and $\mathrm{K}$-feldspar are from
Dinter et al. (1995). Rb-Sr ages on muscovite and biotite are from Papadopoulos and Kilias (1985), Del Moro et al. (1990) and Wawrzenitz and Krohe (1998). U-Pb ages on titanite, xenotime and zircon are from Dinter et al. (1995), Liati and Gebauer (1999) and Liati (2005). Vertiskos, Kerdilion and Sideronero are names of tectonic units; Pangeon and Thasos are geographic notations 
(e.g. Mposkos and Krohe 2000; Ovtcharova et al. 2002; Liati 2005; Turpaud and Reischmann 2009; Jahn-Awe et al. 2010). They were formed during Middle Jurassic to Cretaceous convergence in the upper plate of the subduction zone between Africa and Europe and underwent subsequent extension in Palaeogene and Neogene time (e.g. Dinter and Royden 1993; Sokoutis et al. 1993; Krohe and Mposkos 2002).

\section{The Southern Rhodope Core Complex}

The SRCC (Brun and Sokoutis 2007) is located in the south-west of the Rhodope Massif. It is composed of three main units, the upper, intermediate and lower Rhodopean terranes (Burg et al. 1996; Fig. 2). The superposition of these three units is related to the Cretaceous-Eocene convergence that affected not only the Rhodope but also parts of the SMM (Burg et al. 1990, 1996; Ricou et al. 1998). The core itself, also called the Drama window (Burg et al. 1996), consists of rocks of the lower terrane. The Drama window is overlain in the north by units of the intermediate terrane, termed in this region Sideronero or West Thracian gneiss complex (e.g. Dinter et al. 1995; Krohe and Mposkos 2002). The Drama window and the Sideronero complex are separated by the Nestos thrust (Fig. 2). In the south-west, the Drama window is overlain along the Kerdilion detachment by rocks of the intermediate and upper terrane, also known as Vertiskos unit (Kockel et al. 1971). The rocks outcropping between the Kerdilion detachment and the Strymon Valley detachment (Dinter and Royden 1993; Sokoutis et al. 1993; Fig. 2) belong to the Kerdilion unit (Kockel et al. 1971). The Vertiskos and the Kerdilion units together constitute the southern extension of the SMM (Kockel et al. 1971). Recent studies consider the Kerdilion unit as part of the Rhodope (Georgiev et al. 2010).

The Drama window (lower terrane) consists mostly of massive marbles intercalated with amphibolite and metapelite layers bearing upper greenschist facies mineral assemblages (e.g. Dinter et al. 1995). The metamorphic rocks display a generally flat-lying foliation. The time of the greenschist facies metamorphic event has not been established.

The Sideronero complex (part of the intermediate terrane) comprises various gneisses metamorphosed to amphibolite facies locally reaching granulite facies. Some rocks, mainly the basic lithologies, have preserved relics of a previous eclogite facies metamorphism (Liati 1986; Mposkos 1989; Liati and Seidel 1996). The high-pressure events yield $\mathrm{U}-\mathrm{Pb}$ zircon ages of $\sim 145 \mathrm{Ma}$ in the area to the north of Xanthi (Liati and Gebauer 2001; Liati 2005; Fig. 2), of $51 \mathrm{Ma}$ to the north of Drama (Liati 2005) and of 42-40 Ma near Thermes (Liati and Gebauer 1999; Liati et al. 2004; Fig. 2). The Kerdilion unit, the rest of the intermediate terrane, is largely composed of migmatitic gneisses, amphibolites and marbles.

The Vertiskos unit (upper terrane) is composed of schists, gneisses, amphibolites and scattered ultrabasites (Burg et al. 1995). The rocks were equilibrated under upper greenschist to lower amphibolite facies metamorphism during late Early Cretaceous (Papadopoulos and Kilias 1985).

Parts of the SRCC have experienced a high-temperature stage leading to partial melting. Migmatites occur on Thasos, in the Kerdilion unit and in the Sideronero complex (e.g. Liati 2005; Brun and Sokoutis 2007). In the Sideronero complex, partial melting is dated at $39-40 \mathrm{Ma}$ (Liati 2005; Liati and Gebauer 1999; Liati et al. 2004; Fig. 2).

During the Cenozoic, several plutons intruded the SRCC. The major bodies are the Vrondou, Xanthi and Kavala (or Symvolon) plutons (Fig. 2). The Xanthi pluton was emplaced between 34 and $30 \mathrm{Ma}$ (Liati 1986) and seals the Nestos thrust in the east (Liati 1986; Dinter 1998). The Vrondou pluton is in general undeformed with mylonitic deformation developed only in its western part. This western mylonitic part of the Vrondou may have been emplaced in earliest Miocene (Kaufman 1995) while the eastern undeformed section is assumed to have been intruded contemporaneously with the Xanthi pluton (Dinter et al. 1995). K-Ar hornblende ages indicate minimum values for the emplacement of the eastern Vrondou between $33 \pm 2$ and $29 \pm 1 \mathrm{Ma}$ (Marakis 1969) while dated deformational structures in the surrounding rocks constrain the maximum emplacement age to $36 \mathrm{Ma}$ (Dinter 1994). The Kavala pluton is strongly mylonitic (e.g. Kokkinakis 1979). Its intrusion age based on $\mathrm{U}-\mathrm{Pb}$ on titanite is constrained at 21-22 Ma (Dinter et al. 1995; Fig. 2). This age is very similar to the $\mathrm{Rb}-\mathrm{Sr}$ ages of the metamorphism in the host rock of 23-18 Ma (Del Moro et al. 1990; Fig. 2), implying rapid cooling following the emplacement.

The crystalline rocks of the Drama window as well as of Kerdilion and Vertiskos are partly covered by Miocene to Quaternary lacustrine to marine sediments deposited in the tectonically controlled by steep normal fault basins (e.g. Strymon, Drama and Nestos basins; Fig. 2).

Generally, the core-complex-related extension along the SRCC is thought to have occurred from early Miocene until late Pliocene (Dinter and Royden 1993; Sokoutis et al. 1993; Wawrzenitz and Krohe 1998). However, some early geochronological data from the SRCC (e.g. Harre et al. 1968) points to an earlier initiation of the extension, possibly in the middle Eocene (ages in the Kerdilion unit, Fig. 2; Brun and Sokoutis 2007).

Identification of the major detachment fault, responsible for the exhumation of the SRCC, is still not well constrained. Earlier suggestions (Dinter and Royden 1993; Sokoutis et al. 1993; Wawrzenitz and Krohe 1998) assigned the Strymon Valley detachment as the main structure, 
whereas, more recently, Brun and Sokoutis (2007) suggested that the Kerdilion detachment was responsible for the major exhumation in the SRCC.

The deformation in the SRCC was related to the formation of rather uniformly oriented NE-SW to ENE-WSW stretching lineation (Brun and Sokoutis 2007). Brun and Sokoutis (2007) relate the lineation in the metamorphic rocks with the Oligocene-Miocene extension due to the fact that it bears a similar orientation as within the deformed early Miocene Kavala pluton. Additionally, in this pluton, the sense of shear criteria consistent with top-to-the-SW to top-to-the-WSW direction of movement has been reported (Dinter and Royden 1993; Sokoutis et al. 1993). It must be emphasised that an older, thrust-related lineation reported from the SRCC (Burg et al. 1990, 1996; Ricou et al. 1998) has the same orientation, which leads Brun and Sokoutis (2007) to conclude that both thrusting and the extension occurred under similar stretching directions. The Kerdilion detachment was described as thick mylonitic zone with kinematic criteria indicating a top-to-the-WSW sense of shear (Brun and Sokoutis 2007). Brun and Sokoutis (2007) suggested that this detachment controlled the exhumation of the core complex from middle Eocene to middle Oligocene time. On the contrary, the Strymon Valley detachment surface represents a brittle structure (Dinter and Royden 1993). Below this detachment, a regional southwest-dipping mylonitic fabric overprinting the old structures was related to the extensional tectonics (Dinter and Royden 1993). Therefore, the Strymon Valley detachment has accommodated continuous ductile to brittle deformation during the exhumation of the footwall. The extension, related to the activity along this detachment, is constrained to between 16 and $3.5 \mathrm{Ma}$ (Dinter 1998). Dinter and Royden (1993) reported a SW $\left(243^{\circ}\right)$ transport direction of the hanging wall with respect to its footwall.

\section{Analytical methods}

The FT method on apatite and zircon were applied to various rocks, sampled from both the hanging wall and the footwall of the major detachments recognised along the SRCC in order to unravel the time of the cooling and exhumation either side of these structures. The $[\mathrm{U}-\mathrm{Th}-(\mathrm{Sm})] / \mathrm{He}$ method on apatite was applied to rocks from both sides of the Nestos and the Xanthi fault to constrain the final cooling of these rocks below $\sim 70{ }^{\circ} \mathrm{C}$ and ultimately to identify any later movement along the faults.

Whole rock samples were crushed, and apatite and zircon grains were recovered by conventional heavy liquid and magnetic separation methods. Apatite grains for FT analysis were mounted in epoxy resin, polished and etched with $5.5 \mathrm{~N} \mathrm{HNO}_{3}$ for $20 \mathrm{~s}$ at $21{ }^{\circ} \mathrm{C}$. Zircon grains were mounted in Teflon, polished and etched in a eutectic mixture of $\mathrm{KOH}$ and $\mathrm{NaOH}$ at $220{ }^{\circ} \mathrm{C}$ for $10-20 \mathrm{~h}$. Irradiation was carried out at the OSU facility, Oregon State University Radiation Center, USA. Microscopic analysis was completed using an optical microscope with a Kinetek computer driven stage (Dumitru 1995). The magnifications used were $1250 \times$ (dry) for apatite and $1600 \times$ (oil) for zircon. All ages were determined using the $\zeta$ (zeta) approach (Hurford and Green 1983) with a $\zeta$ value of $416 \pm 13(1 \sigma)$ for apatite and CN5 standard glass, and $133 \pm 2.5(1 \sigma)$ for zircon and CN1 standard glass (Table 1, analyst EW). Ages are reported as central ages (Galbraith and Laslett 1993) with a $2 \sigma$ error.

The temperatures at which fission tracks in apatite and zircon partially anneal (i.e. partial resetting) are not sharply defined. The temperature range within which partial track annealing occurs is known as the partial annealing zone (PAZ). The effective closure of the system lies within this PAZ and depends on the overall cooling rate and kinetic properties of the host mineral. The specific PAZ for apatite lies between 60 and $110{ }^{\circ} \mathrm{C}$ (Green and Duddy 1989; Corrigan 1993), with a mean effective closure temperature of $110 \pm 10{ }^{\circ} \mathrm{C}$ (Gleadow and Duddy 1981).

Unfortunately, knowledge of zircon annealing is less advanced, and a wide-range of temperature intervals has been published for the PAZ of zircon. Yamada et al. (1995) suggested temperature limits of $\sim 390-170{ }^{\circ} \mathrm{C}$, whereas Tagami and Dumitru (1996) and Tagami et al. (1998) suggested temperature limits of $\sim 310-230{ }^{\circ} \mathrm{C}$. Recently, in his overview on the zircon FT method, Tagami (2005) reported temperature ranges for the closure temperature between $\sim 300$ and $200{ }^{\circ} \mathrm{C}$. Accordingly, we use a value of $250 \pm 50{ }^{\circ} \mathrm{C}$ for the mean effective closure temperature and the $200-300{ }^{\circ} \mathrm{C}$ temperature interval for the PAZ.

Horizontal confined track lengths in apatite were measured at a magnification of $1250 \times$ (dry), together with etch pit diameters (Dpar), which are used as a kinetic parameter, which in turn has an influence on fission track annealing (Carlson et al. 1999). Possible time $(t)$-temperature $(T)$ paths were derived using the HeFTy programme of Ketcham (2005). Input parameters are FT age, track-length distribution and Dpars. As a time-temperature constraint, one large $t-T$ box was chosen, in order to give the model as much freedom as possible to move through the PAZ, and a smaller box corresponding to the ZFT age and the zircon closure temperature. An inverse Monte Carlo algorithm with a multikinetic annealing model (Ketcham et al. 2007) was used to generate a large number of $t-T$ paths which are compared to the input data. The Kolmogorov-Smirnov statistical test was used to test the goodness of fit (GOF) between modelled and measured track-length distributions, with merit values of 0.5 and 0.05 for good and acceptable fits, respectively. The best-fitting thermal history obtained 


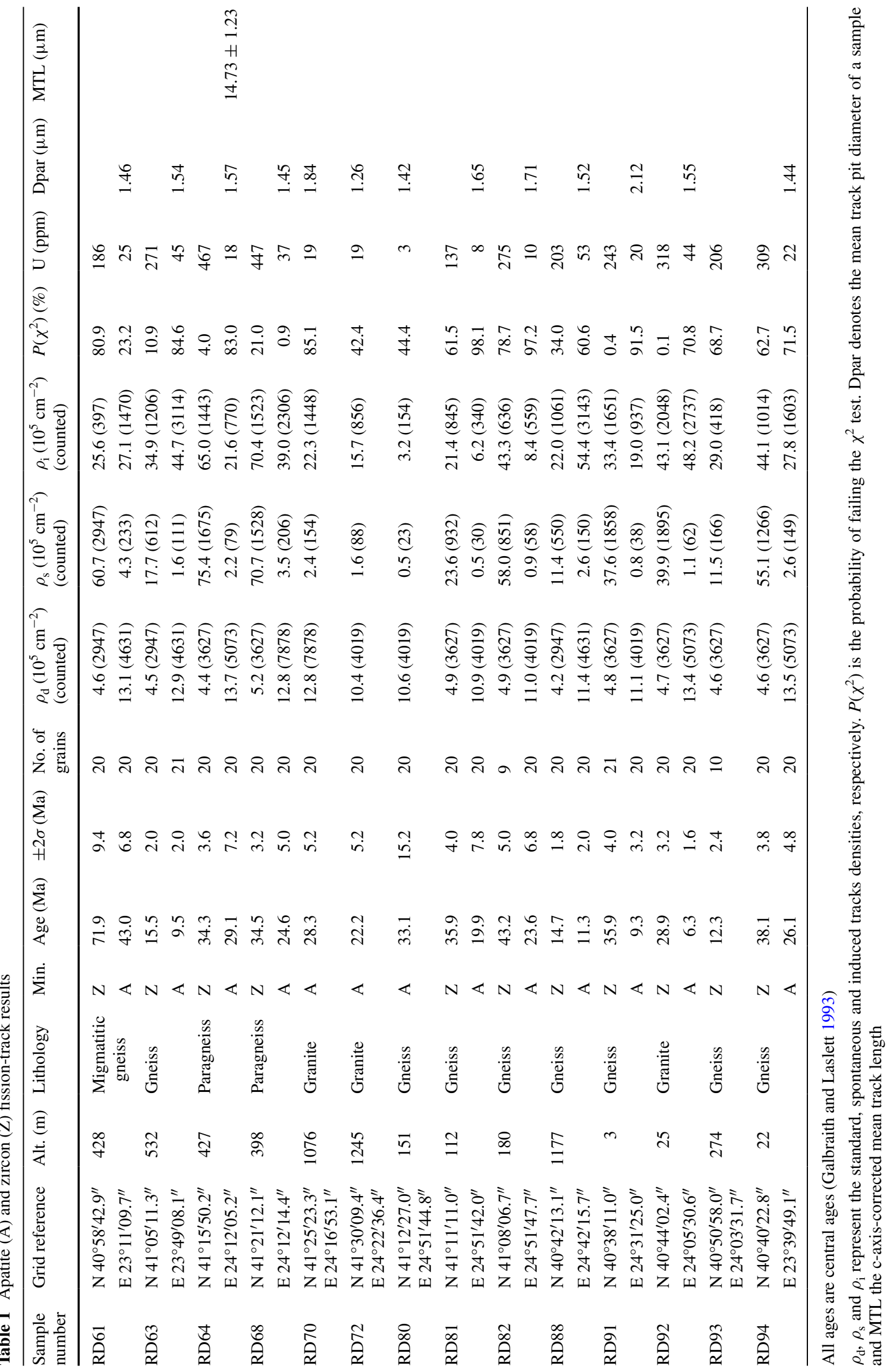


Table 2 Apatite [U-Th-(Sm)]/He results

\begin{tabular}{|c|c|c|c|c|c|c|c|c|c|c|}
\hline Samples & Grain & Age (Ma) & $\pm(\mathrm{Ma})$ & $\mathrm{U}(\mathrm{ppm})$ & Th (ppm) & $\mathrm{Sm}(\mathrm{ppm})$ & $\mathrm{Th} / \mathrm{U}$ & $\mathrm{He}(\mathrm{nmol} / \mathrm{g})$ & Mass (mg) & $F_{\mathrm{t}}$ \\
\hline \multirow[t]{2}{*}{ RD64 } & RD64-2 & 46.9 & 16.6 & 0.16 & 1.91 & 0.41 & 12.16 & 0.11 & 3.20 & 0.69 \\
\hline & RD64-3 & 23.7 & 1.4 & 7.58 & 9.49 & 7.46 & 1.25 & 0.79 & 1.40 & 0.62 \\
\hline Mean age \pm 2 SEM & & 35.3 & 23.2 & & & & & & & \\
\hline \multirow[t]{3}{*}{ RD68 } & RD68-1 & 27.9 & 1.7 & 31.65 & 2.41 & 98.89 & 0.08 & 3.86 & 14.30 & 0.78 \\
\hline & RD68-2 & 27.6 & 1.7 & 30.71 & 3.20 & 112.62 & 0.10 & 3.39 & 5.00 & 0.70 \\
\hline & RD68-3 & 34.8 & 2.1 & 26.85 & 3.32 & 145.78 & 0.12 & 4.26 & 7.10 & 0.79 \\
\hline Mean age \pm 2 SEM & & 30.1 & 4.8 & & & & & & & \\
\hline \multirow[t]{3}{*}{ RD80 } & RD80-1 & 14.0 & 0.6 & 2.84 & 0.66 & 6.70 & 0.23 & 0.16 & 5.60 & 0.70 \\
\hline & RD80-2 & 14.9 & 0.9 & 2.26 & 0.31 & 8.19 & 0.14 & 0.15 & 5.40 & 0.76 \\
\hline & RD80-3 & 17.3 & 2.9 & 1.38 & 0.57 & 7.93 & 0.41 & 0.09 & 2.70 & 0.63 \\
\hline Mean age \pm 2 SEM & & 15.4 & 2.0 & & & & & & & \\
\hline \multirow[t]{3}{*}{ RD81 } & RD81-1 & 17.0 & 0.4 & 6.95 & 0.78 & 13.70 & 0.11 & 0.46 & 5.00 & 0.70 \\
\hline & RD81-2 & 16.7 & 0.2 & 8.51 & 1.05 & 11.75 & 0.12 & 0.61 & 10.90 & 0.76 \\
\hline & RD81-3 & 11.8 & 0.3 & 5.60 & 6.17 & 20.55 & 1.10 & 0.35 & 6.10 & 0.76 \\
\hline Mean age \pm 2 SEM & & 15.1 & 3.4 & & & & & & & \\
\hline \multirow[t]{3}{*}{ RD82 } & RD82-1 & 17.4 & 0.3 & 8.25 & 0.45 & 10.34 & 0.05 & 0.63 & 7.80 & 0.79 \\
\hline & RD82-2 & 14.4 & 0.3 & 5.11 & 0.47 & 8.96 & 0.09 & 0.33 & 9.60 & 0.80 \\
\hline & RD82-3 & 20.2 & 0.4 & 4.63 & 1.16 & 2.99 & 0.25 & 0.42 & 7.60 & 0.79 \\
\hline Mean age \pm 2 SEM & & 17.4 & 3.4 & & & & & & & \\
\hline
\end{tabular}

Ages are reported as single-grain ages and their mean value. The error of the mean is given as $2 \times$ SEM (standard error of the mean). SEM is calculated from the age data of the single analysis and the number of analysis $(N)$ per sample $(\mathrm{SEM}=\sigma / \sqrt{N}) . F_{\mathrm{t}}$ is the alpha ejection correction factor (Farley et al. 1996; Farley 2002)

by the model is not necessarily the only possible. Other thermal histories may possibly match the data similarly well, and thus, it is important to consider both the resulting better models, and the many other geological constraints to determine the most acceptable geological path.

Apatite [U-Th- $(\mathrm{Sm})] / \mathrm{He}$ analyses were performed at the University of Kansas following procedures similar to those reported in House et al. (2000) and Farley and Stockli (2002). Measurements were carried out on 2-3 single grains per sample. Helium was degassed using a $20 \mathrm{~W}$ Nd:YAG laser and subsequently measured on a quadrupole mass spectrometer. Uranium, thorium and samarium were measured on a VG Plasmaquad-2 ICP-MS. Ages were corrected for $\alpha$-ejection using the $F_{\mathrm{T}}$ ejection correction (Farley et al. 1996; Farley 2002). Ages are reported as the average values of the two to three single grains \pm 2 standard errors of the mean (SEM, Table 2). The closure temperature for the apatite minerals (Wolf et al. 1998) depends mainly on (1) the diffusivity of helium in the lattice of the mineral, (2) on the dimensions of the diffusion domain (=usually the size of the dated crystal) and (3) on the cooling rate. As in other geochronological methods (e.g. FT), the closure temperature is not a sharp boundary. Consequently there is a mineral- and method-specific "partial retention temperature zone" (PRZ), where the accumulation of helium is not proportional to time. In apatite, for example, in the temperature range between 75 and $40{ }^{\circ} \mathrm{C}$ at cooling rate of
$1{ }^{\circ} \mathrm{C} / \mathrm{myr}$, part of the continuously forming He gas diffuses out of the crystal within a few million years (Farley 2000).

\section{Results}

Zircon fission-track ages

Eleven samples yielded zircon fission-track (ZFT) ages ranging from 71.9 to $12.3 \mathrm{Ma}$ (Table 1; Fig. 3). The youngest ages ranging between 15.5 and $12.3 \mathrm{Ma}$ (RD63, 88, 93) come from the footwall of the Strymon Valley detachment close to its trace. In the Kerdilion unit (hanging wall of the Strymon Valley detachment) as well as in the area close to the Nestos thrust, the ages range between 34 and $38 \mathrm{Ma}$ (Figs. 3, 4). The two oldest samples come from the hanging wall of the Kerdilion detachment from the Vertiskos unit $(71.9 \pm 9.4 \mathrm{Ma}, \mathrm{RD} 61)$ and the hanging wall of the Xanthi fault from the upper terrane (43.2 \pm 5.0 Ma, RD82; Fig. 3).

Apatite fission-track ages and track-length modelling

Thirteen apatite fission-track (AFT) ages range from 43.0 to 6.3 Ma (Table 1; Fig. 3). As with the ZFT ages, the youngest AFT ages, ranging between $\sim 11$ and $\sim 6 \mathrm{Ma}$, come from the footwall of the Strymon Valley detachment close to its trace 


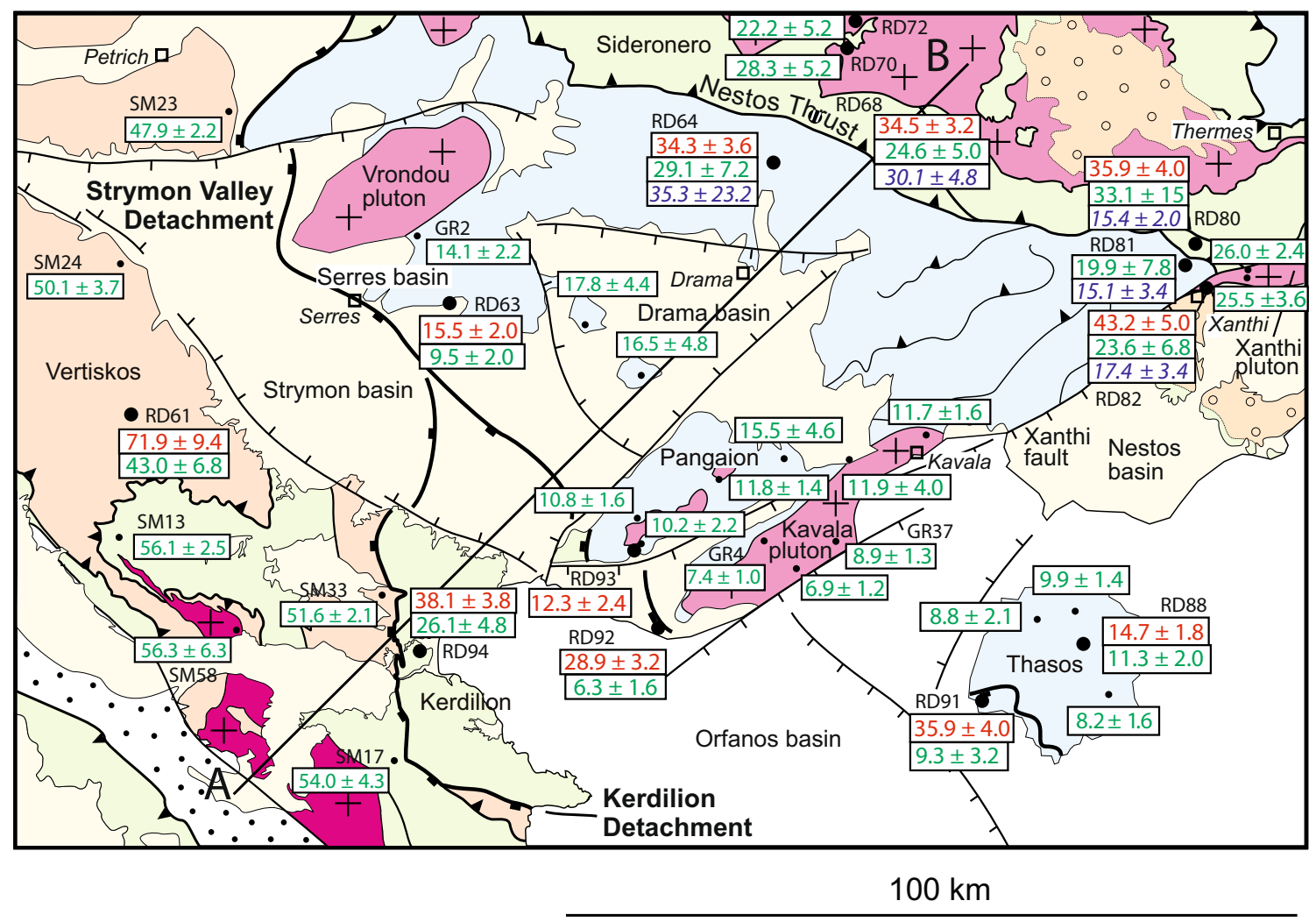

- $43.2 \pm 5.0$ ZFTage $\pm 2 \sigma[\mathrm{Ma}]$ $23.6 \pm 6.8$ AFT age $\pm 2 \sigma[\mathrm{Ma}]$ $17.4 \pm 0.3$ AHe age \pm 2 SEM $[\mathrm{Ma}]$ (this study)
- $16.5 \pm 4.8$ AFT age $\pm 2 \sigma[\mathrm{Ma}]$

(Bigazzi et al., 1994; Kyriakopoulos et al., 1996;

Hejl et al., 1998 and Kydonakis et al., 2014)

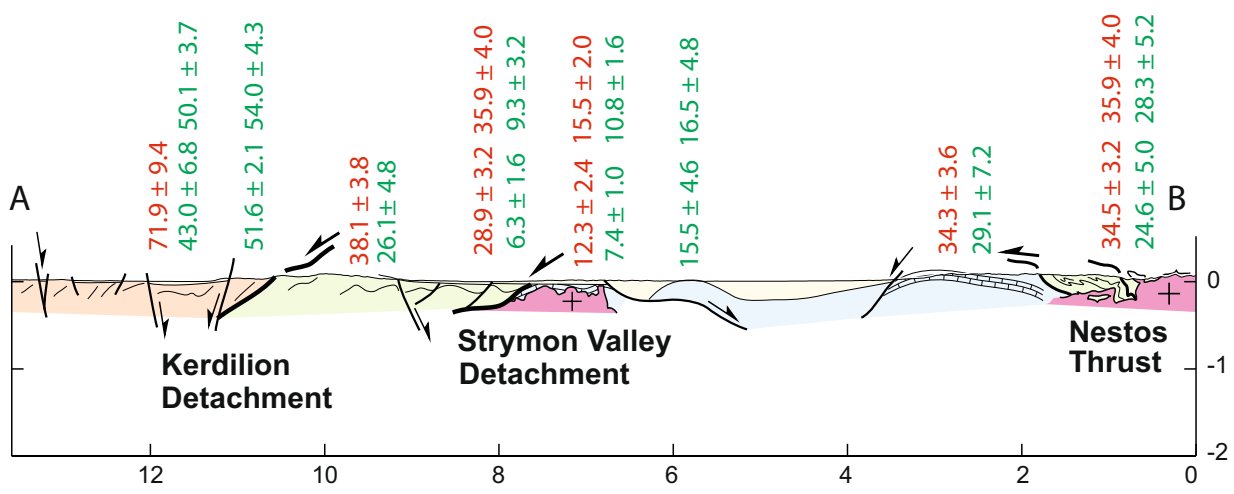

$x 10^{4} \mathrm{~m}$

Fig. 3 Geological map of the SRCC with results for zircon and apatite fission-track dating (AFT and ZFT) and apatite [U-Th-(Sm)]/ He dating (AHe). FT ages are reported as central ages (Galbraith and Laslett 1993) $\pm 2 \sigma$ error. For the AHe ages, a mean value of the sin-

(Figs. 3, 4). However, in addition, two exceptionally young ages of $9.3 \pm 3.2 \mathrm{Ma}(\mathrm{RD} 91)$ and $6.3 \pm 1.6 \mathrm{Ma}(\mathrm{RD} 92)$ occur in the hanging wall of the Strymon Valley detachment (Figs. 3, 4). Samples with intermediate ages of 30-20 Ma are observed in the Kerdilion unit and close to the Nestos gle-grain ages \pm 2 SEM (standard error of the mean) is given. For calculation of SEM, see Table 2. See Fig. 2 for legend. The previously published FT ages are from Bigazzi et al. (1994), Kyriakopoulos et al. (1996), Hejl et al. (1998) and Kydonakis et al. (2014)

thrust. The oldest AFT age, like its zircon equivalent, is obtained from the Vertiskos unit $(43.0 \pm 6.8 \mathrm{Ma}$, RD61). The regional pattern is emphasised by the cross section A-B on Fig. 4, whereby regardless of altitude, the youngest ages occur in the centre of the SRCC. 

fission-track ages (ZFT and AFT) and apatite [U-Th-(Sm)]/ $\mathrm{He}$ ages (AHe) projected onto a SW-NE-oriented, schematic profile. Profile line $A-B$ is indicated in Figs. 2 and 3
Fig. 4 Zircon and apatite

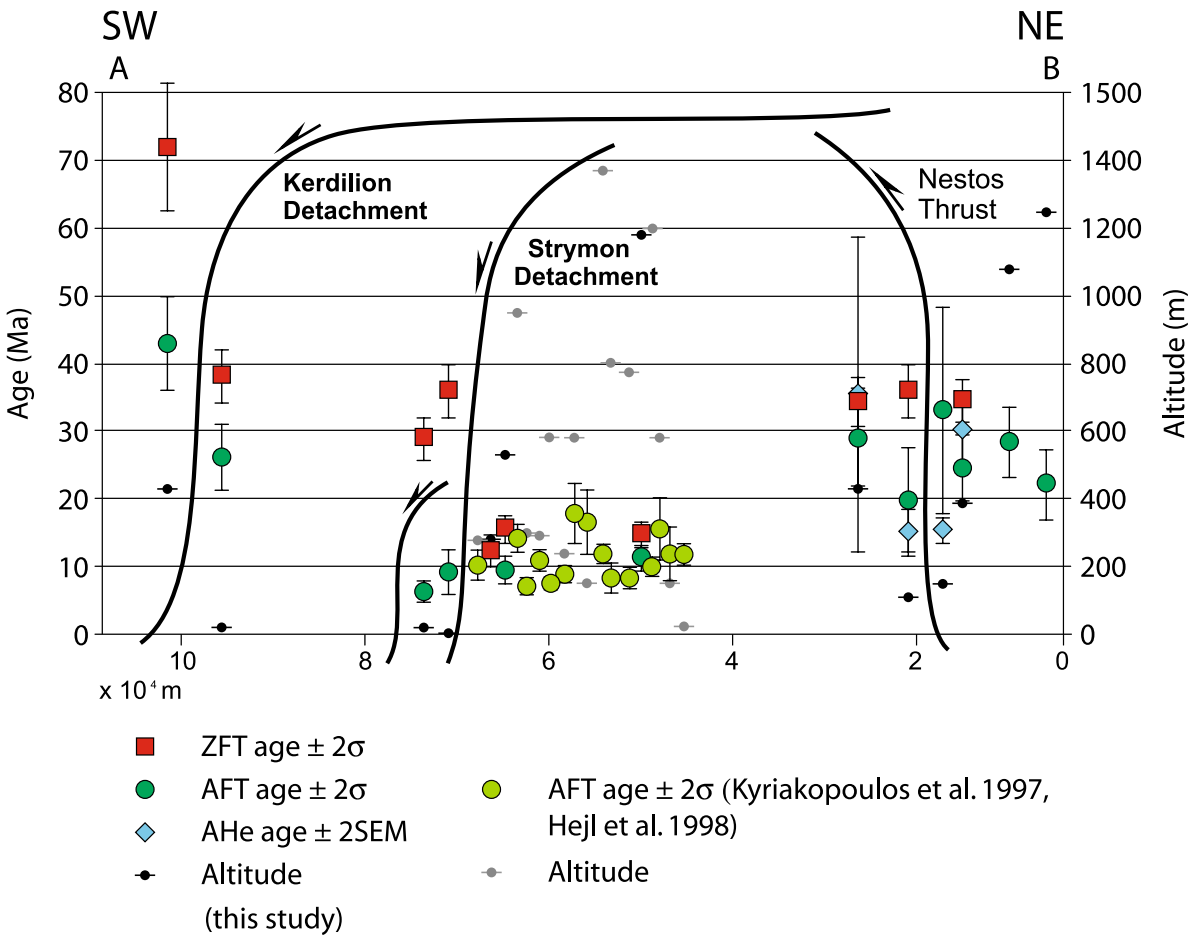

Fig. 5 Inverse temperaturetime model for sample RD64 and the track-length histogram of corrected length for confined tracks. In the model, black boxes show the given constraints to the model. The light grey field shows the envelope of possible acceptable paths, while the dark grey lines are possible good fits and the black line the best fit. In order to determine the goodness of fit (GOF), the Kolmogorov-Smirnov statistical test was used. The hashed areas denote the apatite $\left(110-60{ }^{\circ} \mathrm{C}\right.$, Gleadow and Duddy 1981) and zircon $\left(300-200^{\circ} \mathrm{C}\right.$, Tagami 2005) partial annealing zones. Black stars indicate the [U-Th$(\mathrm{Sm})] / \mathrm{He}$ single-grain ages. In the histogram, AFT age apatite fission-track age, $M L T$ mean track length, $n$ number of measured confined track lengths

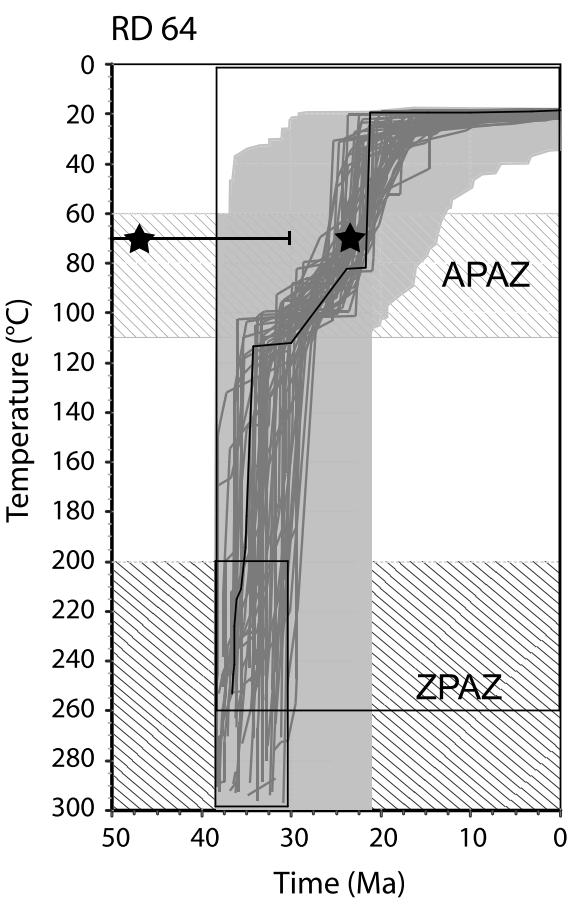

Unfortunately only one sample (RD64), just north of Drama Basin, yielded a sufficient number of horizontal confined track lengths for reliable modelling of its thermal evolution (Fig. 5). The resulting model reveals two distinct cooling events (Fig. 5), a first one between $\sim 40$ and $\sim 30 \mathrm{Ma}$ from 300 to $110^{\circ} \mathrm{C}$ and a second between $\sim 25$ and $\sim 20 \mathrm{Ma}$ from 80 to $<60^{\circ} \mathrm{C}$. These two events are separated by a period of relative quiescence during which the sample remained at temperatures between 110 and $80{ }^{\circ} \mathrm{C}$.

Apatite [U-Th-(Sm)]/He ages

In general there was insufficient material left after FT analysis to carry out many [U-Th-(Sm)]/He datings. The 
two sample sites in the north, from both sides of the Nestos thrust (RD64, RD68, Fig. 3) yield [U-Th-(Sm)]/He ages of $35.3 \pm 23.2$ and $30.1 \pm 4.8$ Ma that are identical within error to their AFT ages. The three sample sites on the south-eastern edge of the Nestos thrust and close to the Xanthi fault yield much younger ages of 17-15 Ma. Sample RD82 (17.4 $\pm 3.4 \mathrm{Ma})$ collected from the hanging wall of Xanthi fault has a relatively older (but still overlapping at 2 sigma) age than the two footwall samples RD80 and RD81 (15.4 \pm 2.0 and $15.1 \pm 3.4 \mathrm{Ma})$.

\section{Interpretation and discussion}

Fission-track age patterns

The new FT analysis combined with existing geochronological data reveals a quite distinct cooling pattern with respect to the Kerdilion and Strymon Valley detachments. A strong control on the age pattern is exerted by the structural elements of the region (Figs. 3, 4). The data are in general consistent with what could be expected from a core complex-older ages in the hanging wall and younger in the later-exhuming footwall.

Generally the youngest zircon ages occur in the footwall of the Strymon Valley detachment in the proximity of its trace (within about $20 \mathrm{~km}$ of the fault, Fig. 3). Older ages occur in the lower and intermediate terranes outcropping in the northeast near the Nestos thrust, as well as for the Kerdilion unit in the south-west, which forms the hanging wall of the Strymon Valley detachment but is yet part of the footwall of the Kerdilion detachment (Fig. 3). The oldest age is from the Vertiskos unit, in the hanging wall of the Kerdilion detachment (RD 61, 71.9 \pm 9.4 Ma). This sample however is also at a higher altitude relative to those from the hanging wall of both detachments (428 m, Fig. 4), and therefore, the age may perhaps be partly a consequence of its elevation. However, the zircon FT age difference across the Kerdilion detachment is geographically consistent with the distribution of higher-temperature chronometers (Fig. 2). Thus, the age difference across the Kerdilion detachment for the full range of closure temperatures from about 500 to $300{ }^{\circ} \mathrm{C}$ clearly supports the notion that this fault was acting as a detachment from at least $40 \mathrm{Ma}$ onwards (Harre et al. 1968), as proposed also by Brun and Sokoutis (2007). A prominent change in the zircon ages is evident also across the Strymon Valley detachment (Figs. 3, 4). The ages in the footwall are between 17 and $15 \mathrm{Ma}$ while those in the immediate hanging wall are 36 and $29 \mathrm{Ma}$ (Fig. 4).

Apatite FT ages reveal a somewhat similar broad regional distribution, with generally younger ages in the core region of the SRCC. However, samples from both sides of the Strymon Valley detachment, unlike the zircon distribution, are now similar excepting sample RD94 $(26.1 \pm 4.8 \mathrm{Ma})$ which was taken some $30 \mathrm{~km}$ to the west of the detachment (Figs. 3, 4). The oldest apatite FT age, as for the zircon FT, is from the hanging wall of the Kerdilion detachment (RD 61, 43.0 $\pm 6.8 \mathrm{Ma}$ ).

The zircon and apatite FT age distribution across the SRCC confirms that the faults were operating as detachments in the region. Small exceptions will be discussed below. With these new FT ages, in combination with previous published geochronological and structural data, a new model for the thermotectonic evolution of the SRCC is proposed.

\section{A proposed evolutionary model of the SRCC}

Cretaceous thrusting led to thickening of the crust in the Rhodope area along the European margin (e.g. Burg et al. 1996; Gautier et al. 1999). In the studied area, any possible activities along the Nestos thrust during the Cenozoic (Turpaud and Reischmann 2009; Krenn et al. 2010) ceased by $34 \mathrm{Ma}$ as is evidenced by the similar FT and [U-Th$(\mathrm{Sm})] / \mathrm{He}$ ages on both sides of the structure (Fig. 3). This is in agreement with the fact that the Xanthi pluton (dated at 34-30 Ma, Liati 1986) seals the thrust. The exact onset of the extension, in the area of the SRCC, is difficult to determine but most probably it started in the middle Eocene (Brun and Sokoutis 2007) as suggested by the contrast in the thermochronological ages across the Kerdilion detachment, with older ages at about $42 \mathrm{Ma}$ in the footwall (K-Ar on muscovite and biotite, Harre et al. 1968; Fig. 2) and $\sim 190-80 \mathrm{Ma}$ in the hanging wall (K-Ar data on muscovite and biotite, Harre et al. 1968, Papadopoulos and Kilias 1985; Fig. 2). Recent apatite FT studies along the Vertiskos unit (Fig. 3), which is part of the hanging wall of the detachment, suggested that this unit cooled through the apatite PAZ during the latest Cretaceous (Kydonakis et al. 2014).

The FT model of sample RD64, north of Drama, shows an earlier, relatively rapid cooling event (Fig. 5) between $\sim 40$ and $\sim 30 \mathrm{Ma}$. This rapid cooling event most probably corresponds to the onset of postthrusting extension and the development of the Kerdilion detachment (Fig. 6a; Brun and Sokoutis 2007). This corroborates also with the $\mathrm{K}-\mathrm{Ar}$ ages from the footwall of the Kerdilion detachment which are between 42 and 31 Ma (Kerdilion unit, Fig. 2, Papadopoulos and Kilias 1985; Harre et al. 1968; Liati 1986). Although the area from which the $\mathrm{K}-\mathrm{Ar}$ ages were obtained is at some distance from sample RD64 (Figs. 2, 3), we suggest that they were all been exhumed during the activity of this detachment associated with the unroofing of the entire core complex. The minimum duration of the extension along the Kerdilion detachment could be constrained by the 
Fig. 6 Evolutionary model of the Southern Rhodope Core Complex during the Cenozoic [modified from Brun and Sokoutis (2007)]
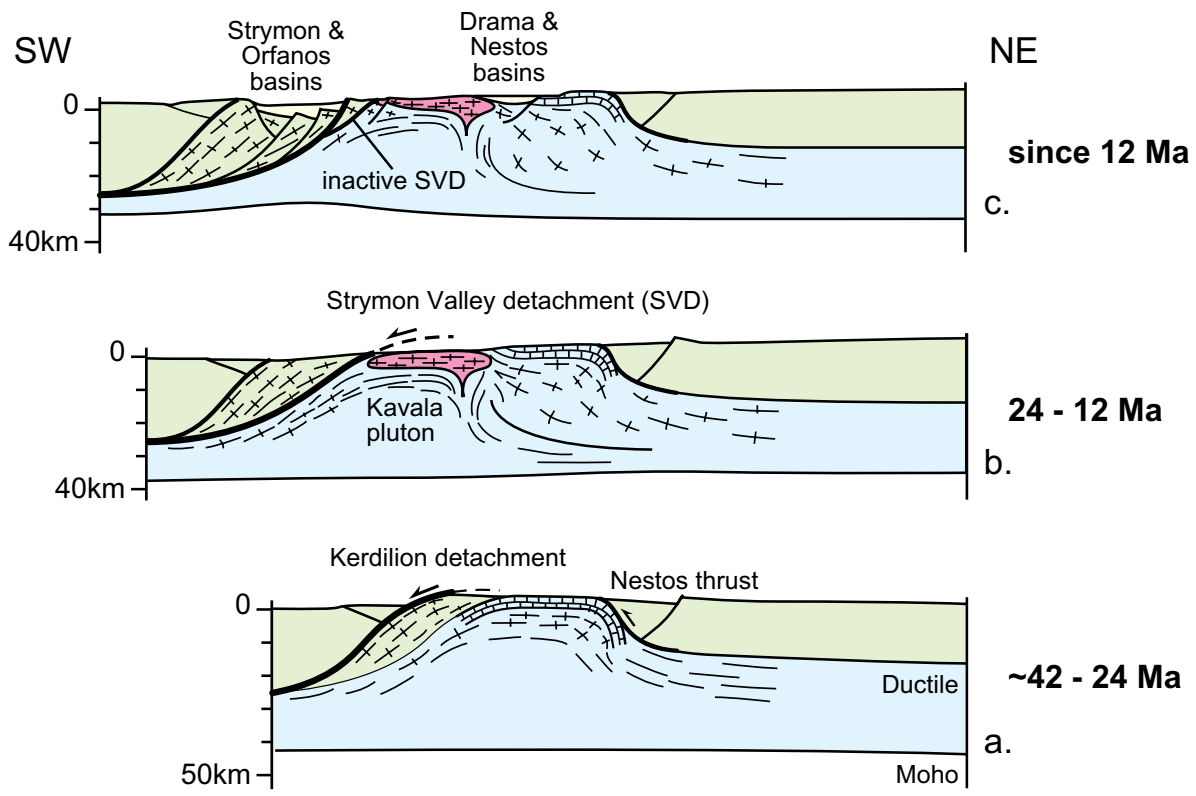

Upper and Intermediate Terranes

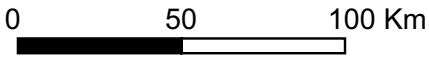

LowerTerrane

(Drama window) zircon and apatite FT ages from its footwall in the Kerdilion unit (sample RD94) and in the area of the Nestos thrust from the Drama window (sample RD64) as well as probably those from the Sideronero unit (samples RD68, RD80 and RD82). Those samples were being exhumed, through the zircon and apatite FT closure temperature, along the footwall of the Kerdilion detachment until at least $24 \mathrm{Ma}$ (the youngest apatite FT age of sample RD82, Fig. 3). Sample RD91, from Thasos island (Fig. 3), probably cooled below the zircon FT closure temperatures during the same exhumationa event. The fact that the rocks from the footwall of the Kerdilion detachment were exhumed to the temperatures as low as $\sim 60{ }^{\circ} \mathrm{C}$ (lower limit of the apatite PAZ) suggests that the movement along this structure was not only related to the ductile deformation but also to the movement of the rocks within the brittle crustal levels.

The Strymon Valley detachment started to control the exhumation of the SRCC most probably after $24 \mathrm{Ma}$ (Fig. 6b; Dinter and Royden 1993; Dinter et al. 1995; Wawrzenitz and Krohe 1998), resulting in renewed rapid cooling inside the dome (Fig. 3). All the FT ages as well as the higher geochronological data from the immediate footwall of the detachment are younger than $24 \mathrm{Ma}$ (Figs. 2, 3). Sample RD64 which was firstly exhumed by the Kerdilion detachment to the temperatures below the zircon FT closure temperature was now exhumed to temperatures below $60{ }^{\circ} \mathrm{C}$ due to the faulting along the Strymon
Valley detachment. The AFT data model of this site (Fig. 5) records the onset of this second cooling event at about $25 \mathrm{Ma}$.

Along the footwall, cooling from about 300 to below $60{ }^{\circ} \mathrm{C}$ between $\sim 17$ and $\sim 12 \mathrm{Ma}$ is suggested from the combination of the zircon FT ages of samples close to the Strymon Valley detachment (RD63, RD93 and RD88) and apatite FT ages of samples far from the detachment (sample GR2 and those from the eastern slope of Pangaion Mt. and the inselbergs along the Drama basin, Figs. 2, 3).

The migration of the strain localisation in the core complex and formation of a second detachment are clearly shown by the geochronological data, but the driving forces for this change are not clearly established. Thermomechanical numerical models of core complex evolution illustrate that with the increase of the extension the zone of maximum exhumation might migrate towards the centre of the dome (Tirel 2005). Brun and Sokoutis (2007) have suggested that this unusual evolution of the SRCC, which corresponds to the initial conditions of these numerical models, could be a consequence of more than $120 \mathrm{~km}$ extension and related crustal thinning. An alternative scenario might relate the onset of the Strymon Valley detachment, inside the core, with the syntectonic emplacement of the Kavala and Vrondou plutons according to the model presented by Lister and Baldwin (1993) stipulating that the core complex formation could be direct result of plutonic activity beneath 
the gneiss dome. On the other hand, the emplacement of these plutons could be well governed by the evolution of the Strymon Valley detachment. In the southern part of the Drama window, the detachment was formed partially along the contact with the Kerdilion unit (Fig. 3), suggesting a reactivation of the former thrust contact between these two units (Fig. 6b). The segment of the Strymon Valley detachment outcropping on Thasos was alternatively interpreted as a flat-ramp-type structure where marble layers intercalated between gneisses acted as a décollement (Brun and Sokoutis 2007).

Whatever triggered the formation of a second detachment, it should be mentioned that the multiple generation of such low-angle faults during the evolution of a single extensional core complex is not an unusual phenomenon [see the discussion in Lister and Davis (1998)]. Therefore, we suggest that both detachments may join the same ductile shear zone in the lower crust (Fig. 6b). It is evident that the mechanism of the formation of the Strymon Valley detachment and its relationship with the Kerdilion detachment are still not well understood. It is worth emphasising that the former is cutting through the latter and continues in its hanging wall in the northern part of the study area (Fig. 2).

The extension along the studied area and the exhumation of the rocks from the SRCC continued after $12 \mathrm{Ma}$ (Fig. 6c). This process is constrained not only by the apatite FT ages of the samples from the footwall (Fig. 3) of the Strymon Valley detachment but also from its hanging wall (samples RD92 and RD91, Fig. 3). This suggests that most probably the major movements along the Strymon Valley detachment had ceased by this time and the extension was accommodated by the movements along the individual brittle normal faults, some of them cutting the detachment (Figs. 2, 3). These dominantly normal faults are related to the formation of several basins, not only along the hanging wall (Orfanos and Strymon basins, Fig. 2) but also along the footwall of the Strymon Valley detachment (Drama and Xanthi basins, Fig. 2). The timing of the sedimentation in the area is compatible with these findings. The deposits from the Strymon basin are of $\sim 9.8 \mathrm{Ma}$ (based on the age of fossil rodent in non-marine clastic sediments north of Serres, Armour-Brown et al. 1977); unfortunately older sediments that also crop out in that area did not yield fossils suitable for dating (Dinter and Royden 1993). The sediments from the Strymon basin in Bulgaria contain mammal fauna yielding a middle Miocene age (15.97-11.61 Ma; Kojumdgieva et al. 1982).

The fact that the youngest apatite FT ages (between $12 \mathrm{Ma}$ and $6 \mathrm{Ma}$, Fig. 3) are from the east shoulder of the Orfanos and Strymon basin (Fig. 3) could be explained by the fact that these basins experienced the maximum subsidence (up to $4 \mathrm{~km}$, Sokoutis et al. 1993), and therefore, its

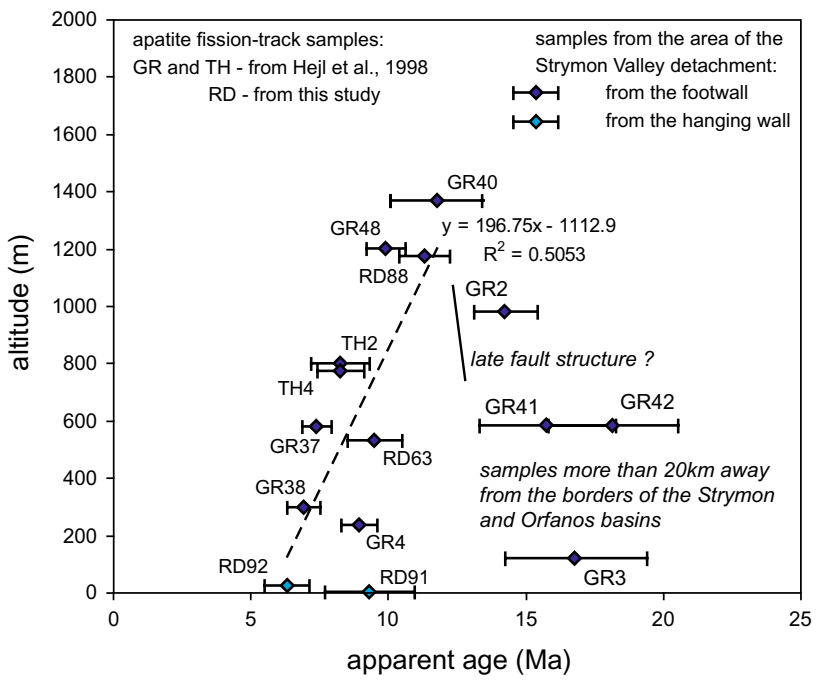

Fig. 7 Apatite FT ages versus elevation plot for samples near the Strymon Valley detachment

shoulders have probably experienced the maximum uplift. The oldest syn-tectonic sediments deposited in the Orfanos basin date back to the Tortonian (11.61-7.25 Ma) (Büttner and Kowalczyk 1978; Kousparis 1979; Lalechos 1986), which corresponds to our estimates for the activities along the brittle faults in the area. The denudation during this period (12-6 Ma) was probably at a lower rate than the previous detachment-related event. A denudation rate of about $0.2 \mathrm{~mm} / \mathrm{a}$ was obtained from the slope of the age-altitude curve for the apatite FT samples from both sides of the Strymon Valley detachment over a time period of 12-6 Ma (Fig. 7). Those samples that do not fit the correlation line are from areas far from the eastern shoulders of the Orfanos and Strymon basin, which obviously have experienced the maximum exhumation during this time frame.

This Neogene extension in the study area was already reported as an unusual evolution of extensional core complex because instead of being located mostly along the hanging wall, the basins and the normal faults are largely dispersed across the whole core complex (Brun and Sokoutis 2007). The lack of a time gap between the previous extensional stage and the onset of the sedimentation in these basins suggests that they are part of the same extensional process (Brun and Sokoutis 2007). Dinter and Royden (1993) suggested that the NW-SE-trending normal faults and NE-SW mostly dextral strike-slip faults (such as Xanthi fault), responsible for the basin formation, sole into a NE-dipping detachment zone analogous to the Strymon Valley system but of opposite polarity. According to their model, this detachment zone initiates SW of the Thermaikos basin and is linked to the right-slip displacement along the North Anatolian Fault (Fig. 1). The cooling of the rocks below the apatite FT closure temperature $\left(110 \pm 10{ }^{\circ} \mathrm{C}\right.$; 


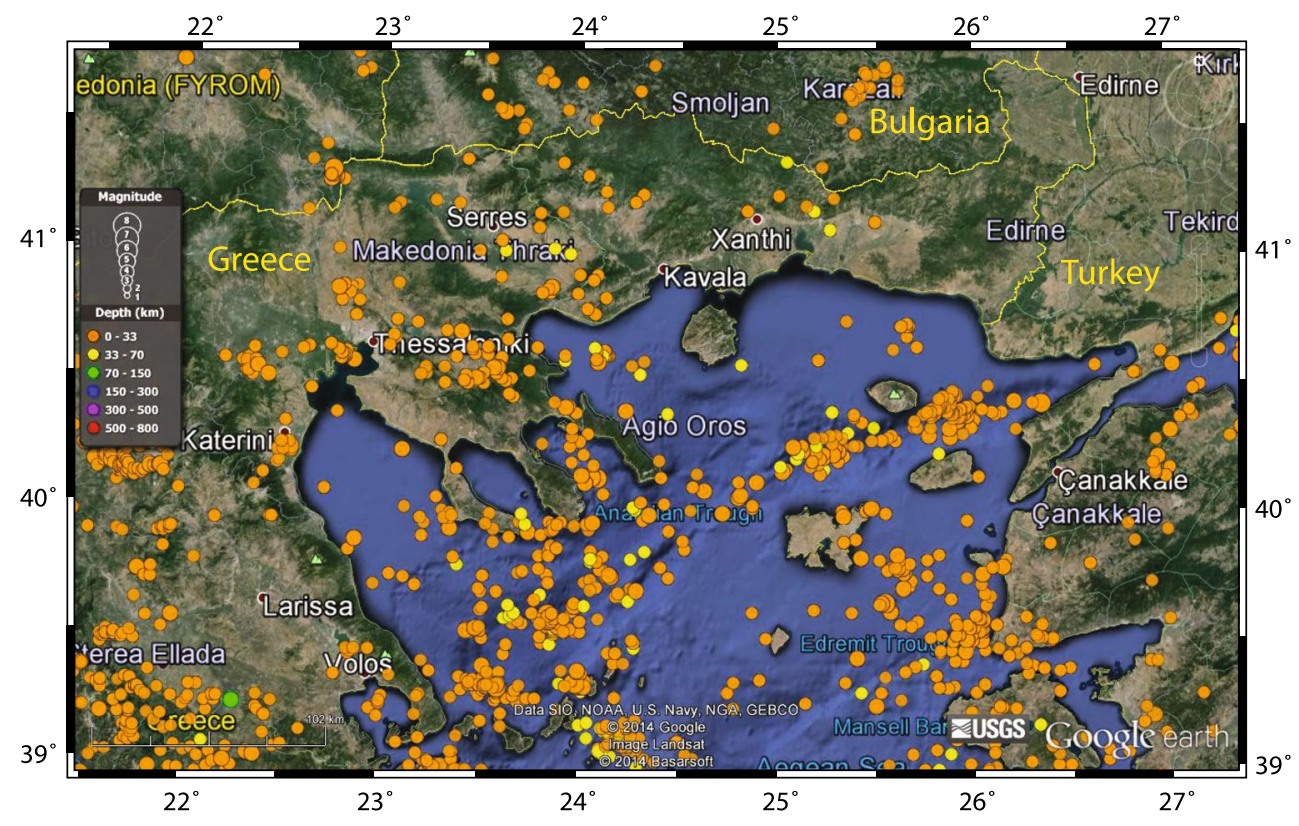

Fig. 8 Seismicity map from the USGS (http://earthquake.usgs.gov/earthquakes/search/) reporting the seismic activity between 2005 and 2014 in the Northern Aegean region

Gleadow and Duddy 1981) during this extensional stage implies more than $3 \mathrm{~km}$ of exhumation along the hanging walls of the normal faults. Therefore, it could be suggested that these faults are deeply rooted into a lower crustal ductile shear zone and that the major exhumation could be accommodated by the formation of yet another major detachment fault cutting through the hanging wall of the Strymon Valley detachment which therefore becomes inactive (Fig. 6c).

We do not have any evidence for the eventual cooling and exhumation after $6 \mathrm{Ma}$, which is the youngest apatite FT age (sample RD92) in the study area. This of course does not mean that the tectonic activity in the study area has ceased. A map of the Aegean region showing the seismicity from 2005 until 2014 (USGS, http://earthquake. usgs.gov/earthquakes/search/) indicates that the studied area has been active to a minor extent until today (Fig. 8).

Cooling to temperatures below $\sim 70{ }^{\circ} \mathrm{C}$

The apatite [U-Th- $(\mathrm{Sm})] / \mathrm{He}$ ages of samples from the area of the Nestos thrust and the Xanthi fault may allow some constraints on the final cooling of this area below $\sim 70{ }^{\circ} \mathrm{C}$ (Fig. 3) to be made.

Samples RD64 and RD68 have large errors but both overlap within two-sigma error of the AFT and ZFT data (Fig. 4). This suggests that there was probably no differential movement on the Nestos thrust after $\sim 30 \mathrm{Ma}$ in this region, confirming the conclusions made on the basis of the ZFT ages.
Young helium apatite ages (between 17 and $15 \mathrm{Ma}$, Fig. 3) occur on both sides of the Xanthi fault. Previously normal and strike-slip movements have been reported along the Xanthi fault (Burchfiel et al. 2000) but it is unclear at what time the fault was initiated. The structure was previously interpreted as a ramp related to the movement along the Strymon Valley detachment (Dinter 1998) or as an individual detachment (Krohe and Mposkos 2002). Koukouvelas and Pe-Piper (1991) state that the Xanthi fault controlled the emplacement of the Xanthi pluton and was therefore active from 34 to $30 \mathrm{Ma}$. On the other hand, sediment studies suggest that the fault only dates back to $\sim 14 \mathrm{Ma}$, as the oldest syn-tectonic sediments in the Nestos basin (Fig. 2) are Serravallian (13.8$11.6 \mathrm{Ma}$ ) in age (Kousparis 1979; Gautier et al. 1999). He ages of footwall samples yielding values of $\sim 15 \mathrm{Ma}$ (RD80, 81), compared to the hanging wall sample RD82 of $\sim 17 \mathrm{Ma}$, could be indicating some normal faulting at this time. These data do not discard an older strike-slip movement along the Xanthi fault as pure strike-slip movements are generally not recorded by the thermochronological data.

\section{Conclusions}

Extension causing the exhumation and cooling of the South Rhodope Core Complex began from the middle Eocene (Brun and Sokoutis 2007). The exhumation was controlled by different fault systems: 
1. The Kerdilion detachment initiated the exhumation along the SRCC at the latest at $42 \mathrm{Ma}$ and controlled it until about $24 \mathrm{Ma}$.

2. Between $\sim 24$ and $\sim 12 \mathrm{Ma}$, the Strymon Valley detachment started to control the exhumation. It ceased at about $12 \mathrm{Ma}$.

3. Since $12 \mathrm{Ma}$ brittle normal faults, some of them cutting the Strymon Valley detachment were responsible for the final cooling of the basement rocks within this area and the formation of syn-tectonic sedimentary basins. Activity along these brittle normal faults lasted until $6 \mathrm{Ma}$ or probably even until today as indicated by recent seismic activity in the area.

In a broader regional context, extension in the Aegean region is considered to be a consequence of continuous subduction and accretion of smaller continental blocks and intermediary oceanic basins, which trigger slab rollback and trench retreat (e.g. Brun and Faccenna 2008; Forster and Lister 2009). The first phase of exhumation in the SRCC (accommodated by the Kerdilion detachment) was presumably caused by back-arc extension coeval with the subduction of the Pindos Ocean (Brun and Faccenna 2008). The second phase (accommodated by the Strymon Valley detachment) is coeval with core complex formation in the Cyclades (starting at $\sim 20 \mathrm{Ma}$, Gautier et al. 1999 and references therein) and a result of back-arc extension initiated by the onset of the subduction of the Eastern Mediterranean Ocean. The last phase of exhumation might just result from a continuing back-arc extension, or it has been triggered by the westward extrusion of Anatolia along the North Anatolian Fault (NAF, Fig. 1). The NAF has been active since < $16 \mathrm{Ma}$ (Gautier et al. 1999) and supports the extension in the Aegean region.

Acknowledgments This study was supported by ETH research grant number TH-4 05-2. We thank Dimo Dimov, Dimitrios Sokoutis and Pieter Vermeesch for their collegial support in the field, as well as discussions and advice including that with Jean-Pierre Brun. Constructive reviews by Istvan Dunkl and Giulio Viola have helped to improve the quality of the paper.

\section{References}

Armour-Brown A, de Bruijn H, Maniati C, Siatos G, Niesen P (1977) The geology of the Neogene sediments north of Serrai and the use of rodent faunas for biostratigraphic control. In: Proceedings of the sixth colloquium for the geology of the Aegean region, Athens, vol 6, pp 615-622

Bigazzi SG, Christofides G, Moro AD, Kyriakopoulos C (1994) A contribution to the evolution of the Xanthi pluton (northern Greece): the apatite fission track analysis. Boll Soc Geol It 113:243-248

Bonev N, Burg, J-P, Ivanov Z (2006) Mesozoic-Tertiary structural evolution of an extensional gneiss dome - the Kesebir-Kardamos dome, eastern Rhodope (Bulgaria-Greece). Int J Earth Sci 95:318-340
Brun JP, Faccenna C (2008) Exhumation of high-pressure rocks driven by slab rollback. Earth Planet Sci Lett 272:1-7

Brun JP, Sokoutis D (2007) Kinematics of the southern Rhodope core complex (North Greece). Int J Earth Sci 96:1079-1099

Burchfiel CB, Nakov R, Tzankov T, Royden LH (2000) Cenozoic extension in Bulgaria and northern Greece: the northern part of the Aegean extensional regime. In: Bozkurt E, Winchester JA, Piper JDA (eds) Tectonics and magmatism in Turkey and the surrounding area, vol 173. Geological Society, London, Special Publications, pp 325-352

Burg JP (2012) Rhodope: from Mesozoic convergence to Cenozoic extension. Review of petro-structural data in the geochronological frame. J Virtual Explor 42:1

Burg JP, Ivanov Z, Ricou LE, Dimor D, Klain L (1990) Implications of shear-sense criteria for the tectonic evolution of the Central Rhodope Massif, southern Bulgaria. Geology 18:451-454

Burg JP, Godfriaux I, Ricou LE (1995) Extension of the Mesozoic Rhodope Thrust Units in the Vertiskos-Kerdilion Massifs (Northern Greece). Comptes Rendus De L'Academie Des Sciences Paris 320:889-896

Burg JP, Ricou LE, Ivanov Z, Godfriaux I, Dimov D, Klain L (1996) Syn-metamorphic nappe complex in the Rhodope massif. Structure and kinematics. Terra Nova 8:6-15

Büttner D, Kowalczyk G (1978) Late Cenozoic stratigraphy and paleogeography of Greece-a review. In: Closs H, Roeder D, Schmidt K (eds) Alps, Apennines, Hellenides. IUCG Scientific Report 38, pp 494-501

Carlson WD, Donelick RA, Ketcham RA (1999) Variability of apatite fission-track annealing kinetics: I. Experimental results. Am Mineral 84:1213-1223

Del Moro A, Kyriakopoulos K, Pezzino A, Atzori P, Lo Giudice A (1990) The metamorphic complex associated to the Kavala plutonites: an $\mathrm{Rb}-\mathrm{Sr}$ geochronological, petrological and structural study. Geol Rhodopica 2:143-152

Dinter DA (1994) Tectonic evolution of the Rhodope metamorphic core complex, northeastern Greece. PhD thesis, Massachusetts Institute of Technology, Cambridge

Dinter DA (1998) Late Cenozoic extension of the Alpine collisional orogen, northeastern Greece: origin of the north Aegean basin. Geol Soc Am Bull 110:1208-1226

Dinter DA, Royden L (1993) Late Cenozoic extension in northeastern Greece-Strymon Valley detachment system and Rhodope metamorphic core complex. Geology 21:45-48

Dinter DA, Macfarlane A, Hames W, Isachsen C, Bowring S, Royden L (1995) U-Pb and Ar-40/Ar-39 geochronology of the Symvolon granodiorite-implications for the thermal and structural evolution of the Rhodope metamorphic core complex, Northeastern Greece. Tectonics 14:886-908

Dumitru TA (1995) A new computer automated microscope stage system for fission-track analysis. Nucl Tracks Radiat Meas 21:575-580

Farley KA (2000) Helium diffusion from apatite: general behavior as illustrated by Durango fluorapatite. J Geophys Res Solid Earth 105:2903-2914

Farley KA (2002) (U-Th)/He dating: techniques, calibrations, and applications. Rev Mineral Geochem 47:819-844

Farley KA, Stockli DF (2002) (U-Th)/He dating of phosphates: apatite, monazite, and xenotime. In: Kohn MJ, Rakovan J, Hughes JM (eds) Conference on phosphates-geochemical, geobiological and materials importance. Mineralogical Society of America, Golden, pp 559-577

Farley KA, Wolf RA, Silver LT (1996) The effects of long alpha-stopping distances on (U-Th)/He ages. Geochim Cosmochim Acta 60:4223-4229

Forster M, Lister G (2009) Core-complex-related extension of the Aegean lithosphere initiated at the Eocene-Oligocene transition. 
J Geophys Res Solid Earth 114:B02401. doi:10.1029/200 7JB005382

Galbraith RF, Laslett GM (1993) Statistical-models for mixed fissiontrack ages. Nucl Tracks Radiat Meas 21:459-470

Gautier P, Brun JP, Moriceau R, Sokoutis D, Martinod J, Jolivet L (1999) Timing, kinematics and cause of Aegean extension; a scenario based on a comparison with simple analogue experiments; basin dynamics and basin fill; models and constraints, part I. Tectonophysics 315:31-72

Gleadow AJW, Duddy IR (1981) A natural long-term track annealing experiment for apatite. Nucl Tracks Radiat Meas 5:169-174

Görur N, Okay AI (1996) A fore-arc origin for the Thrace Basin, NW Turkey. Geol Rundsch 85:662-668

Green PF, Duddy IR (1989) Some comments on paleotemperature estimation from apatite fission track analysis. J Petrol Geol 12:111-114

Harre W, Kockel F, Kreuzer H, Lenz H, Mueller P, Walther HW (1968) Ueber Rejuvenationen im Serbo-Mazedonischen Massiv (Deutung radiometrischer Altersbestimmungen). Rep Int Geol Congr 6:223-236

Hejl E, Weingartner H, Vavliakis E, Psilovikos A (1998) Macrorelief features and fission-track thermochronology of the Rila-Rhodope massif (eastern Macedonia, Greece). Zeitschrift fuer Geomorphologie 42:517-530

House MA, Farley KA, Stockli D (2000) Helium chronometry of apatite and titanite using Nd-YAG laser heating. Earth Planet Sci Lett 183:365-368

Hurford AJ, Green PF (1983) The zeta age calibration of fission-track dating. Chem Geol 41:285-317

Jahn-Awe S, Froitzheim N, Nagel TJ, Frei D, Georgiev N, Pleuger J (2010) Structural and geochronological evidence for Paleogene thrusting in the Western Rhodopes, SW Bulgaria: elements for a new tectonic model of the Rhodope Metamorphic Province. Tectonics 29:TC3008

Jahn-Awe S, Pleuger J, Frei D, Georgiev N, Froitzheim N, Nagel TJ (2012) Time constraints for low-angle shear zones in the Central Rhodopes (Bulgaria) and their significance for the exhumation of high-pressure rocks. Int J Earth Sci 101:1971-2004

Kaufman PS (1995) Extensional tectonic history of the Rhodope metamorphic core complex, Greece and geophysical modeling of the Halloran Hills, California. PhD thesis, Massachusetts Institute of Technology, Cambridge

Ketcham RA (2005) Forward and inverse modeling of low-temperature thermochronometry data, low-temperature thermochronology: techniques, interpretations, and applications. Rev Mineral Geochem Chantilly Mineral Soc Am 58:275-314

Ketcham RA, Carter A, Donelick RA, Barbarand J, Hurford AJ (2007) Improved modeling of fission-track annealing in apatite. Am Mineral 92:799-810

Kockel F, Mollat H, Walther HW (1971) Geologie des Serbo-Mazedonischen Massivs und seines mesozoischen Rahmens (Nordgriechenland). Geol Jahrb 89:529-551

Kojumdgieva E, Nikolov I, Nedjalkov P, Busev A (1982) Stratigraphy of the Neogene in Sandanski Graben. Geol Balc 12:69-81

Kokkinakis A (1979) Zum Faltenbau des Symvolongebirges und des Gebietes von Kavala (Griechisch-Ostmakedonien). Annales Geologiques des Pays Helleniques 30:398-420

Koukouvelas I, Pe-Piper G (1991) The Oligocene Xanthi pluton, northern Greece: a granodiorite emplaced during regional extension. J Geol Soc 148:749-758

Kounov A, Seward D, Bernoulli D, Burg JP, Ivanov Z (2004) Thermotectonic evolution of an extensional dome: the Cenozoic Osogovo-Lisets core complex (Kraishte zone, western Bulgaria). Int J Earth Sci 93:1008-1024

Kounov A, Seward D, Burg JP, Bernoulli D, Ivanov Z, Handler R (2010) Geochronological and structural constraints on the
Cretaceous thermotectonic evolution of the Kraishte zone (Western Bulgaria). Tectonics 29:TC2002

Kounov A, Graf J, von Quadt A, Bernoulli D, Burg JP, Seward D, Ivanov Z, Fanning M (2012) Evidence for a "Cadomian" ophiolite and magmatic-arc complex in SW Bulgaria. Precambr Res 212-213:275-295

Kousparis D (1979) Seismic stratigraphy and basin developmentNestos Delta area, Northeastern Greece. PhD thesis, University of Tulsa, USA

Krenn K, Bauer C, Proyer A, Klötzli U, Hoinkes G (2010) Tectonometamorphic evolution of the Rhodope orogen. Tectonics 29. doi: $10.1029 / 2009$ TC002513

Krohe A, Mposkos E (2002) Multiple generations of extensional detachments in the Rhodope Mountains (northern Greece): evidence of episodic exhumation of high-pressure rocks. In: Blundell DJ, Neubauer F, von Quadt A (eds) The timing and location of major ore deposits in an evolving orogen, vol 204. Geological Society, London, pp 151-178

Kydonakis K, Gallagher K, Brun JP, Jolivet M, Gueydan F, Kostopoulos D (2014) Upper Cretaceous exhumation of the western Rhodope Metamorphic Province (Chalkidiki Peninsula, northern Greece). Tectonics 33:1113-1132. doi:10.1002/2014TC003572

Kyriakopoulos KG, Magganas AC, Norelli P, Bigazzi G, Del Moro A, Kokkinakis A (1996) Thermochronological evolution of symvolon and pangeon plutons and their country rocks, Kavala area, N. Greece; an apatite fission track analysis. Neues Jahrbuch fuer Mineralogie 11:519-529

Lalechos N (1986) Correlations and observations in molassic sediments in onshore and offshore areas of northern Greece. Miner Wealth 42:7-34

Liati A (1986) Regional metamorphism and overprinting contact metamorphism of the Rhodope zone, near Xanthi (N. Greece). PhD thesis, Braunschweig, Technische Universität Carolo-Wilhelmina

Liati A (2005) Identification of repeated Alpine (ultra) high-pressure metamorphic events by U-Pb SHRIMP geochronology and REE geochemistry of zircon: the Rhodope zone of Northern Greece. Contrib Miner Petrol 150:608-630

Liati A, Gebauer D (1999) Constraining the prograde and retrograde $\mathrm{P}-\mathrm{T}-\mathrm{t}$ path of Eocene HP rocks by SHRIMP dating of different zircon domains: inferred rates of heating, burial, cooling and exhumation for central Rhodope, northern Greece. Contrib Miner Petrol 135:340-354

Liati A, Gebauer D (2001) Palaeozoic as well as Mesozoic sedimentation and polymetamorphism in Central Rhodope (N Greece) as inferred from U-Pb SHRIMP-dating of detrital zircons. J Conf Abstr 6:315

Liati A, Seidel E (1996) Metamorphic evolution and geochemistry of kyanite eclogites in central Rhodope, northern Greece. Contrib Miner Petrol 123:293-307

Liati A, Gebauer D, Fanning CM (2004) The duration of exhumation processes in (U)HP terranes-a geochronological approach applied to the Rhodope terrane, N Greece, vol 1. In: "Geoscience Africa 2004", the birth and growth of continents, abstract, pp 384-385

Lister GS, Baldwin LS (1993) Plutonism and the origin of metamorphic core complexes. Geology 21:607-610

Lister GS, Davis GA (1998) The origin of metamorphic core complexes and detachment faults formed during Tertiary continental extension in the northern Colorado River region, USA. J Struct Geol 11:65-94

Marakis GI (1969) Geochronologic studies of some granites from Macedonia. Annales Geologiques des Pays Helleniques 21:121-152

Mposkos E (1989) High-Pressure Metamorphism in Gneisses and Pelitic Schists in the East Rhodope Zone (N Greece). Mineral Petrol 41:25-39 
Mposkos E, Krohe A (2000) Petrological and structural evolution of continental high pressure (HP) metamorphic rocks in the Alpine Rhodope Domain (N. Greece). In: Panayides J, Xenophontos C, Malpas J (eds) Proceedings of the third international conference on the Geology of the eastern Mediterranean, vol 3. Ministry of Agriculture, Natural Resources and Environment, Nicosia, pp 221-232

Nagel TJ, Schmidt S, Janák M, Froitzheim N, Jahn-Awe S, Georgiev N (2011) The exposed base of a collapsing wedge-the Nestos Shear Zone (Rhodope Metamorphic Province, Greece). Tectonics 30:TC4009. doi:10.1029/2010TC002815

Ovtcharova M, Cherneva Z, von Quadt A, Peytcheva I (2002) Migmatitic geochronology and geochemistry - a key to understanding the exhumation of the Madan dome (Bulgaria). Geochim Cosmochim Acta 66:A573

Papadopoulos C, Kilias A (1985) Altersbeziehungen zwischen Metamorphose und Deformation im zentralen Teil des Serbomezedonischen Massivs (Vertiskos Gebirge, Nord-Griechenland). Geol Rundsch 74:77-85

Ricou LE, Burg JP, Godfriaux I, Ivanov Z (1998) Rhodope and Vardar: the metamorphic and the olistostromic paired belts related to the Cretaceous subduction under Europe. Geodin Acta 11:285-309

Schmid SM, Bernoulli D, Fügenschuh B, Matenco L, Schefer S, Schuster R, Tischler M, Ustaszewski K (2008) The Alpine-Carpathian-Dinaridic orogenic system: correlation and evolution of tectonic units. Swiss J Geosci 101:139-183

Sokoutis D, Brun JP, van den Driessche J, Pavlides S (1993) A major Oligo-Miocene detachment in southern Rhodope controlling North Aegean extension. J Geol Soc Lond 150:243-246
Tagami T (2005) Zircon fission-track thermochronology and applications to fault studies. Rev Mineral Geochem 58:95-122

Tagami T, Dumitru TA (1996) Provenance and history of the Franciscan accretionary complex: constraints from zircon fission track thermochronology. J Geophys Res 101:11353-11364

Tagami T, Galbraith RF, Yamada R, Laslett GM (1998) Revised annealing kinetics of fission tracks in zircon and geological implications. In: Van den Haute P, de Corte F (eds) Advances in fission-track geochronology. Kluwer Acadedmic Publishers, Dordrecht, pp 99-114

Tirel C (2005) Dynamique de l'extension des domaines épaissis: Dômes métamorphiques et écoulement de la croûte ductile. Mémoires Géosciences Rennes 115:1-247

Turpaud P, Reischmann T (2009) Characterization of igneous terranes by zircon dating: implications for UHP occurrences and suture identification in the Central Rhodope, northern Greece. Int J Earth Sci 99:567-591

Wawrzenitz N, Krohe A (1998) Exhumation and doming of the Thasos metamorphic core complex (S Rhodope, Greece): structural and geochronological constraints. Tectonophysics 285:301-332

Wolf RA, Farley KA, Kass DM (1998) Modeling of the temperature sensitivity of the apatite (U-Th)/He thermochronometer. Chem Geol 148:105-114

Yamada R, Tagami T, Nishimura S, Ito H (1995) Annealing kinetics of fission tracks in zircon: an experimental study. Chem Geol 122:249-258 